\title{
9
}

\section{PLAYING THE RUSSIAN DISINFORMATION GAME}

\section{Information operations from Soviet tactics to Putin's sharp power}

\section{Francesco Bechis}

\section{Information operations (IO): a review of the doctrine}

Like any other major power, Russia has become an efficient actor in the cyberdomain. Information operations (IOs) and state-led propaganda play a primary role in Russian cyber warfare. This is not surprising, given the fact that state-sponsored disinformation has been in place as long as there have been State-actors. Yet during the last two decades, the digital revolution has provided Russia with new tools and tactics that have put the country at the forefront of global information warfare. This process has been accompanied by a continuous evolution of Russian military doctrine on unconventional warfare that has considerably accelerated throughout the last decade. ${ }^{1}$ State-guided weaponisation of information has often been referred to by Western academics as 'hybrid warfare'. ${ }^{2}$ When it comes to definitions, though, one cannot but note how slightly Russian and Western military doctrines over IOs differ from each other. Terms like 'hybrid warfare', 'new-generation warfare', and 'cyberwarfare' have little room in the Russian military science glossary and sometimes are even at odds with it. There are two main reasons why in Moscow one hardly hears discussion of 'cyberwarfare' (kiberwoyna) or IOs in the same way as Western academics and pundits. First, Russia has a truly different view of IOs than the United States or Europe. As Rand Waltzman (2017: 4) has noted, Russian military elites conceive IOs as a "continuous activity, regardless of the state of relations with any government." This means that they see information warfare as an endless state of warfare that is non-reliant on any casus belli, but instead is a pillar of a long-term power strategy. Western states, a glossary provided by the Russian Military Academy of the General Staff explains, rather tend to think of IOs as tactical activities that need to be undertaken in case of hostilities. The second difference lies in the attribution of this kind of operation. Russian military and political élites tend to refer to hybrid warfare as a Western-rooted strategy aimed at undermining its enemies' cohesion. Stating that key elements of the Russian military doctrine 
are instead part of the Western vocabulary seems to be a recurrent method that dates back to the Soviet times. In fact, the Russian government's attention to hybrid warfare came to be world-known after one of those articles Russian top generals wrote seven years ago. The author was General of the Army Valery Gerasimov, Chief of the General Staff of the Russian Federation Armed Forces, still one of the most prominent figures in the Russian military establishment. Since the 21 st century had seen a tendency "toward blurring the lines between the states of war and peace", Gerasimov (2016: 24) noted at the time, traditional warfare had to be re-thought by exploring the possibilities of the new information warfare, which provides States with a competitive against their adversaries. "The role of nonmilitary means of achieving political and strategic goals has grown", the general observed, "and, in many cases, they have exceeded the power of force of weapons in their effectiveness."

\section{The 'Gerasimov doctrine' in the Western debate}

The article soon sparked a lively debate in Western academies over a supposed 'Gerasimov doctrine'. Some scholars like Keir Giles referred to it as one of the turning points in the recent evolution of Russian military doctrine, others argued it was no more than a resumé of Soviet-style military theories (Giles 2016). In an article published in the magazine Foreign Policy, Mark Galeotti claimed to have been the real 'inventor' of the expression back in 2013 (Galeotti 2018). Truth may lie beneath. Whilst Gerasimov's impact on Russian strategic thought must not be overrated, Galeotti's article nonetheless showed the world how deeply rooted hybrid warfare was in Moscow's military doctrine and how the debate had grown inside the Military Academy. Moreover, Gerasimov's references to a new kind of asymmetric warfare in the information space that paved the way to "wide asymmetrical possibilities for reducing the fighting potential of the enemy" revealed the Russian government already had a clear idea on how to use information as a strategic weapon in the cyber-domain (Gerasimov 2016: 27). Russian doctrine on IOs has since passed through a significant evolution. Other terms, like new generation warfare (NGW) or new-type wars (NTW), have taken the stage in public debates and studies promoted by the General Staff (Thomas 2016: 555).

During the last decade, the Western debate over Russian IOs and asymmetrical warfare has grown remarkably. Among the hundreds of prominent scholars who gave an in-depth description of how Russian State-led disinformation and cyberwarfare work today, there is a group of US researchers from the NED (National Endowment for Democracy) who coined a new term to address Russian attempts to exert influence in the information space: 'sharp power' (Cardenal et al. 2017). Presented at first in a report in 2017, this interpretation has gained ground throughout the academic world and had a vast media echo (Messa 2019). While 'soft power' means the ability to attract and co-opt through appeal and attraction, sharp power, the authors argued, is the ability to wield influence that "pierces, penetrates, or perforates the political and information environments in the targeted 
countries" (Cardenal et al. 2017: 6). This seems to be a regular practice for authoritarian states, which came to learn how to turn the advantages of globalisation into a weapon. More precisely, they managed to exploit a 'glaring asymmetry'. Globalisation and the digital revolution have widened the openness of democratic systems. Major authoritarian powers like Russia and China, though, have exploited these spaces on a global scale, while raising barriers and narrowing communication and information spaces at home. Russia has been particularly active in taking advantage of the opportunities provided by the globalisation era and, as mentioned, has learned how to turn this asymmetry into strategic leverage in the information war.

The information sphere, though, is not the only domain where authoritarian states' sharp power comes into action: trade, foreign direct investments, energy supplies, schools and universities, international political and cultural institutions, think tanks, foundations. Mastering control and coercion in all these domains is useful to win over the public opinion of a foreign country and getting leverage in its political system is a valid weapon for sharp power. As the name suggests, it is a 'sharp' form of influence, as it penetrates the targeted national system just as a dagger penetrates flesh. Form and method might even perfectly resemble a classic 'soft power' operation, but sharp power has its own distinctive features, as argued by Cardenal and his colleagues: whatever the tool used, the final goal has little to do with cultural exchanges or public image (Cardenal et al. 2017). Sharp power aims at maximising political leverage.

Even though the NED's work has faced some opposition from top scholars, like soft power's father Joseph Nye, who disputes the idea that sharp power represents a new form of influence (Nye 2018), it deserves credit for having shed light on the ongoing challenge posed by authoritarian states with a new face of the information competition through conventional and unconventional means that is not 'soft' nor comes close to what Joshua Kurlantzick called a "charm offensive." 4

\section{Russia's 'active measures'}

As noted before, the concept of information warfare is not new to Russia's strategic thought. Indeed, it has always been a key component of what Russian intelligence officers, military chiefs, and policy makers have historically referred to as 'active measures' (aktivnye meropriyatiya), or, to cite a well-known definition by American Kremlinologist George Kennan, "measures short of war" (MSW), a set of measures aimed at undermining the enemy's resilience through covert operations in the economic, military, cyber, and information fields. Nevertheless, the tools and tactics that the digital revolution has introduced demand a new theoretical framework to read Russian IOs. Before entering into details about the Russian government's approach to information warfare, it is worth noting how it fits a well-established practice.

Since Soviet times, in Russian military doctrine active measures have been indicated as a set of three main concepts: disinformation (dezinformatsiya), deception (maskirovka), and reflexive control (refleksivnoe upravlenie) (Connable et al. 
2020: 25). None of these is a stand-alone tactic, as they concur to create a holistic approach to warfare within the field of information. Among the three, maskirovka is the oldest, as it first appeared in Russian military academia around 1904, when the Czar and his family were still alive and in charge. To understand how deeply institutionalised this notion is, it suffices to recall that from 1904 to 1929 there has been a school, the Higher School of Maskirovka, where Russian military officials were provided with the basics of this tactic through textbooks and dedicated lessons (Thomas 2004: 239). A comprehensive definition can be found in the work of Roger Beaumont, one of the leading scholars who has studied Soviet disinformation techniques in depth. Maskirovka, he argued, "encompasses a diverse spectrum of stratagems employed to warp the enemy's view of Soviet positions, designs and missions, and to alter the perceptions of their own side and their clients as well" (Beaumont 1982: 3). Recently, Keir Giles has defined it as "the complex of measures devised to confuse the enemy regarding the presence and disposition of forces, their condition, readiness, actions and plans" (Giles 2018: 10). Deception and camouflage are two recurrent elements of any country's military doctrine and hitherto should not be overlooked. What has really made maskirovka a peculiar feature of Russian State action though is its transversal use both in the military and in the political and civilian world. Born in the military academia, the concept has become a State paradigm that encompasses the whole spectrum of government activities. Even though maskirovka is an old-fashioned Soviet-era strategy, some authors maintain that it still has its place in Russian hostile measures. Galeotti, for instance, has described the operations of the 'little green men' who fled Crimea in 2014 before it was annexed by Russia as a classic case of maskirovka, as the confusion and fear they sowed among the Ukrainian military establishment and forces bought time to the Russians and to their local allies, allowing them to gain the commanding positions in Crimea. ${ }^{5}$

\section{Disinformation and reflexive control}

Russian dezinformatsiya is "the practice of misinforming or misleading adversaries (and others) with false information, typically to slow, degrade, or stop effective responses to an associated Russian activity, such as sabotage, cyberattack, or limited military incursion" (Connable et al. 2020: 27). Despite building on Cold War tactics, contemporary Russia's State-led disinformation presents unique features. This is not just due to the use of social media and new technologies, but also because it has changed scope, speed, and volume. Today Russian disinformation campaigns can count on a wholly new set of tools. Social media platforms and the pro-government media environment provide them with a much higher level of discretion than the Soviet ones, making it more difficult to trace them back to government agencies. Christopher Paul and Miriam Matthews (2016) have defined the contemporary model of Russian disinformation as a "Firehose of falsehood", as it presents two distinctive features: "high number of channels and messages and a shameless willingness to disseminate partial truths or outright factions." Multiple 
sources and channels help today's Russian government disinformation efforts reach their targets with much greater efficiency and speed than before. The simultaneous use of government-related media outlets, social networks, and automated bots and trolls grants these campaigns an audience once inconceivable. Moreover, unlike Soviet-era propaganda operations, present disinformation campaigns do not come out as a response to isolated events or threats, but instead they are part of a continuous flow of information channelled both through official and unofficial means. As several studies in the experimental psychology field have shown, repetition helps a message to be successful and accepted by the targeted audience (Petty et al. 2005). In the words of Paul and Matthews, "repetition leads to familiarity, and familiarity leads to acceptance" (Paul and Matthews 2016: 4).

While dezinformatsiya is a relatively recent concept, refleksionoe upravlenie or 'reflexive control', has much deeper roots in Russian military literature. Its first appearances date back more than 30 years ago. Maria Snegovaya has described it as the ability to force a "stronger adversary voluntarily to choose the actions most advantageous to Russian objectives by shaping the adversary's perceptions of the situation decisively" (Snegovaya 2015: 7). A similar interpretation has been offered by Timothy Thomas, who defined reflexive control as "a means of conveying to a partner or an opponent specially prepared information to incline him to voluntarily make the predetermined decision desired by the initiator of the action" (Thomas 2004: 237). Both definitions insist on the same aspect: Russian reflexive control operations are aimed at altering the enemy's perceptions, in order to make him think what they want him to think and do what they want him to do. These operations can leverage different tactics, from isolated military measures to acts of disinformation and diversion (diversiya), which is the tactic of diverting the adversary's attention to divide its forces. To be successful, they usually need to exploit pre-existing vulnerabilities in their targets, which can be individuals (i.e. decision-makers, military chiefs, influential personalities) or wide sections of the population. In the words of Thomas, "chief task of reflexive control is to locate the weak link of the filter, and exploit it" (ibid.: 241). Several cases can be borrowed, both from past and recent times. During the Cold War, the Soviet Union used to set up parades of fake-ICBMs in Moscow to convince the US the Soviets had the latest generation nuclear missiles, altering the enemy's perception of their nuclear arsenal. Knowing dozens of US diplomats, attachés, and undercover agents used to attend these parades, as they provided them with public information over Russian military capabilities, the Russian government filled them with fake missiles, hoping the attendants would then report to domestic intelligence agencies (ibid.: 253).

\section{When theory meets practice: The war with Georgia and Ukraine}

Concrete examples of how the tactics described above have been translated into actions can be drawn from the Russia-Georgia war in 2008, a conflict which is 
considered the first and most significant test bench for Putin's hybrid warfare and Russian IO. As stressed by Giles, the way this confrontation ended provides a clear example of how Russian reflexive control works and can be effective (Giles and Seaboyer 2018: 13). Tensions arose after the maxi-military drill Kavkaz-2008 ended on 4 August. The ongoing movement of Russian troops at the border unrelated to the Russian contingents of the CIS (collective peacekeeping forces), along with the evacuation of civilians in South Ossetia to Russia, let the Georgian government led by President Mikheil Saakashvili, as well as most of the international community, believe Russians were on the edge of storming Tbilisi and overthrowing the government. Rumours and fears eventually led to the evacuation of the city on 9 August. This contributed to the creation of a sense of urgency among EU countries, which ultimately led to the ceasefire agreement signed on the 12 August. Thus, the terms dictated in the peace plan, Giles and Seaboyer wrote, "resulted from a false perception that Georgia could be lost altogether" (ibid.). French President Nicolas Sarkozy's mediation helped Russia get away with an unexpected set of concessions: not only was Moscow allowed to keep its troops on the ground, but it was also given an additional 'security-zone' across the borders of South Ossetia and Abkhazia. This was a textbook case of Russian reflexive control. By letting its adversaries believe a military invasion of Tbilisi was about to happen, Russia got away with more concessions that it could have ever hoped for.

A more recent case where the Russian government has made extensive use of reflexive control techniques is the ongoing war in Ukraine, which started with the annexation of Crimea in 2014. As Snegovaya (2015: 7) pointed out, "the Ukrainian war may well turn into the most relevant testing ground for Russian reflexive control tactics ever." Although not all of the objectives set by Moscow have been accomplished so far, it is undeniable that Putin has achieved some considerable results, notably the decision taken by Western countries to avoid a direct intervention into the conflict, not to mention the divisions sown among NATO allies in one of the toughest tests for the Alliance cohesion. ${ }^{6}$ As in the previous cases, the Ukrainian crisis has seen the deployment of a wide range of strategies from Russian authorities. Denying the presence of Russian forces on the ground and of any link between the Federation and the 'little green men' who poured into the Ukrainian territory six years ago; convincing EU countries that Russia's tools and resources were scarce and therefore the Russian army presence in Ukraine was somehow tolerable; at the same time, promoting an unprecedented set of disinformation campaigns and cyber-warfare operations to spread the narrative of Russia as a 'saviour', the only actor capable of allowing Crimean citizens to rightfully reclaim sovereignty from a corrupt country.

\section{Social media: The disinformation chain}

After this brief overview of the Russian disinformation strategic pillars, it is worth noting how theory meets practice today. Whether the cited notions are still acknowledged by the Russian military and political elites or not, what allows 
the reinterpretation and the putting of these old Soviet-fashioned approaches into practice is the range of new techniques and tools that digitalisation and the Internet have brought. Among these, social media plays a central role in modern Russian State-led IOs. This seems nothing extraordinary at a first glance. Yet, things change when one looks at how institutionalised the Russian government has made its use of media outlets and social media for propaganda and targeted disinformation purposes. Of course, this institutionalisation did not happen overnight. Rather, it is part of a well-established strategy that reflects President Putin's perception of the information landscape as well as his ideas about how it should be controlled. Back in 2013, Putin gave an unambiguous explanation of his long-term plans to put Russia at the forefront of the information competition worldwide. While visiting the new RT (one of the major Russian broadcasters, previously known as Russia Today) headquarters in Moscow, he expressed his hope that Russian media could soon manage to "break the Anglo-Saxon monopoly on the global information streams" (Messa 2019: 43). Later that same year, at the annual news conference, commenting on the future of State media outlets, Putin left no doubts about how he conceives the freedom of information: "There should be patriotically minded people at the head of state information resources" - he told reporters - "people who uphold the interests of the Russian Federation. These are state resources. That is the way it is going to be" (Dougherty 2015). As Paolo Messa (2019: 43) noted, "Post-Soviet Russia's media strategy is a case that is well-known (and very relevant today) of how subtle the boundary can be between political propaganda and information."

There are many reasons why today's social media allows a government to target its adversary in a way that was inconceivable before. First of all, their target is much wider than any information campaign in the past. As Giles pointed out, they can hit entire populations, and reach people "in their natural environment" (Giles and Seaboyer 2018: 34). Second, social media campaigns are far harder to be exposed. Last but not least, they are relatively low-cost compared to the old kinetic techniques through which IOs were carried out. All these features made Putin bet heavily on the social media potential in the information war. The difference between Russia and other major Western countries is the scale, the extent, and the sophistication behind its social media State-led disinformation strategy.

A recent report from RAND Corporation describes the "disinformation chain" underpinning the Kremlin's use of social media to achieve its foreign policy objectives (Connable et al. 2020). On top of the chain is the Russian government. This indeed is what emerged in July 2018 from US special counsel Robert Mueller's 'Russiagate' final report, where 12 Russian agents from the GRU (Main Intelligence Directorate of the General Staft), a long-established Russian foreign military intelligence agency, were indicted for the massive hacking of the National Democratic Committee and US presidential candidate Hillary Clinton's campaign staff. Intelligence agencies, however, are not the only players in the Russian disinformation game. Evidence shows that the majority of the disinformation campaigns channelled through social media are pursued by entities that are not formally linked 
to the government. This category, which represents the second ring of the chain and includes popular media outlets like RT and press agencies like Sputnik, is formed by actors which receive public support from the government and have a key role in conveying the Kremlin's disinformation campaigns, both domestically and abroad. A third ring is then represented by a wide set of entities whose links to the Russian government are often hard to find without an intelligence inquiry. This group includes thousands of webpages and blogs committed to shaping the Russian government's disinformation efforts spreading fake or misinformed stories and injecting fake news into the targeted audiences. The Internet Research Agency (IRA), a well-known troll factory (i.e. an agency specialising in the creation and diffusion of fake social media accounts) based in St. Petersburg, with dozens of employees working daily to fabricate false stories and spread them online, is a major player at this level (Chen 2015). It was cited in the final report of the 'Russiagate' investigation by the US Special Counsel Robert Mueller, which was delivered to the Attorney General William Barr on 22 March 2019. The report defined it as "a Russian organization funded by Yevgeniy Viktorovich Prigozhin", then one of the most prominent Russian oligarchs, and accused it of having conducted "social media operations targeted at large US audiences with the goal of sowing discord in the U.S. political system."7

\section{Who did what? The attribution dilemma}

Another lens through which the Russian disinformation scheme can be understood is deniability. Disinformation is fuelled by a wide range of actors, going from those whose attribution is easy to those that are much harder to relate. State-media giants such as Sputnik News, Channel One, Ruptly, and the All-Russia State Television and Radio Broadcasting Company (VGTRK) belong to the first group. Some of these government-related media outlets, alongside officially independent media like RT, can rely on an amount of resources second to none of the many other world-known broadcasters. RT, for instance, has an outstanding presence on social media, especially on YouTube, where it counts more subscribers than $\mathrm{BBC}$ or Fox News and broadcasts in various languages such as German, French, Arabic, and even Mandarin. However, their level of independence has little to do with the one enjoyed by other global media outlets. To put it in Daniel Fried and Alina Polyakova's (2018: 4) words, "they are arms of the Russian State no more independent than Pravda was during the Soviet period." As a matter of fact, despite a broad offer, the Russian State media environment does not seem to have much room for challenging views of the government's action. This is also due to a strict legal framework that has recently been tightened by a new set of laws introduced in March 2019 establishing fines up to 1.5 million roubles (20,500 euros, approximately) for those who disseminate 'false information' through the media landscape and do not remove it at the request of the Federal Service for Supervision of Communications, Information Technology and Mass Media (Roskomnadzor). These 
laws allow for "the censorship of online journalism and online speech", OSCE Representative on Freedom of the Media Harlem Désir noted. ${ }^{8}$

As noted above, official media outlets are just the tip of the iceberg. Their strength comes from a broad audience. Their weakness lies in their easy attribution. Hence, a second link of the disinformation chain is needed. Blogs, websites, and online newspapers that are not officially affiliated to the Russian government but that nonetheless clearly side with it can prove to be very effective force multipliers of disinformation campaigns. These include news aggregators, data-dump websites, far-right and far-left blogs, often easily recognisable by conspiracy theories and click-bait headlines. Together, they form a 'grey zone': useful for inflating propaganda, they lack direct links to Russian public authorities and yet play a key role in shaping their views and disinformation. Records show that the great majority of these outlets is active in the dissemination of divisive content, mostly with a strong anti-Western bias. Depending on the geographical context, they can exploit different pre-existing cultural and political divisions. For instance, in the so-called 'near abroad', a term that has historically indicated ex-Soviet States such as Ukraine, Belarus, Moldova, Lithuania, Estonia, Latvia, but also states of the Trans-Caucasus region such as Georgia or Armenia, these sites usually insist on the widespread discontent of local populations towards the Western, US-led cultural model and the presence of strong, deeply rooted Russian speaking communities. On the other side, in Europe, they frequently use issues such as immigration, Islam, and sovereignty as leverage against an elitist EU or a declining NATO.

\section{Force multipliers: When bots come into action}

Finally, the lowest level of attribution is reached by the last link of the chain: a network of fake social media accounts, both human-led (trolls) or automated (bots), which are especially useful for amplifying the disinformation and for spreading it on the web while keeping their cover. Here the lines between the information and the cyberspace become blurred. Trolls and bots carry different tasks. The former have a more consolidate presence in the Russian information space. Their main objective is to create content, not just to spread it. In recent years, notably after Putin's return to Kremlin in 2012 and the impressive wave of mass protests that followed, there has been a continuous record of pro-government trolls targeting opposition leaders, opinion-makers, and bloggers. Content created by trolls does not necessarily have to be faked. Indeed, it can well consist of a mixture of realistic claims and fiction, so long as it is presented as credible to the targeted audience. Records show that several disinformation campaigns carried out by pro-Kremlin trolls were built on highly detailed information that was hacked from their victims. This was the case for Sergei Maksimov, a Russian hacker known through the name of 'Torquemada Hell', who, for years, has attacked anti-government bloggers, stealing data and information through spear-phishing 
and then spreading it with the help of trolls and bots. He was convicted for his crimes in Germany (Sanovich 2017: 10).

Unlike trolls, the core task of bots is to act as force multipliers of disinformation. Their distinguishing feature, as the name explains, is to be fully automated. They usually consist of fake social media accounts, especially on Twitter, and act simultaneously, publishing content on a schedule and expanding the reach of Russian trolls as well as State-media content. As previously noted, the more coordinated the disinformation chain, the higher the chance for the message to reach its target. Not surprisingly, most Russian IOs that have been unmasked by Western intelligence in recent years have shown a high degree of coordination between the three levels of the chain. A celebrated textbook case is the 'Lisa case'. On 11 January 2016, in Berlin, during mass migrant public unrest in the city of Cologne, Lisa, a 13-year-old German girl with Russian origins, did not come home from school. Soon after her disappearance was reported to the media by her parents, a joumalist from Channel One, a Russian-language Kremlin TV broadcasting in Germany, suggested that the girl had been raped by migrants while she was out. Once Russian outlets, such as RT Deutsch and Sputnik, picked up the news, it quickly broke through the mainstream media. Eventually it prompted the Russian Minister of Foreign Affairs Sergey Lavrov to condemn Germany's reluctance to investigate the case. In a few hours, a diplomatic case broke out, and the story rapidly entered social media, relaunched by pro-Kremlin Twitter users and Facebook groups and igniting a street protest from hard-right groups in Cologne. The day after the German police revealed that the whole story was fake: Lisa had spent the night at her friend's home. Other examples can be drawn from recent events. The Covid-19 virus worldwide outbreak in February 2020 offered another chance for a widespread disinformation campaign carried on by Russian State media and social media accounts. A report from the EEAS (European Union External Action Service) noticed an increase of disinformation efforts from providers based in Russia or linked to the Kremlin (Rankin 2020). Conspiracy theories describing the virus as a Western plot to benefit pharmaceutical companies appeared on the website of RIA FAN federal agency, while the pro-Kremlin REN TV claimed the virus could be a 'biological weapon' used by US forces against China. This seems to be part of a new path that Russian State media have taken to disseminate false claims against Western countries. Instead of fabricating the fake contents themselves, the EU report shows, they increasingly tend to refer to conspiracy theories originated elsewhere, to avoid accusations. It is a new form of maskirovka but translated into the media sphere. After all, some good old Soviet tactics never get old.

\section{Conclusion}

One of the most common arguments the disinformation 'skeptics' tend to resort to goes as follows: 'should we really care?' Why should we fear that a few Twitter bot accounts or a handful of conspiracy blogs might really have a visible impact on 
one state's political and information environment? While the question is no doubt legitimate, it is also misplaced. As our review tried to demonstrate, websites, blogs, and social network accounts are just the tip of the iceberg. Or, in other words, they are nothing but the last links of the disinformation chain. At the top of it, there often might be a highly sophisticated direction from state actors. No one could be so naïve as to believe that every worldwide state-led disinformation campaign has the Kremlin's stamp on it. As we recalled, disinformation has been in place as long as there have been states. However, the Russian case is one worth studying, for two main reasons. First: it can count on an institutional architecture no other state can claim today. Second: as we showed, today's Russian disinformation relies on a long-standing tradition of Soviet-era military tactics. This has become even clearer after Mr Putin came to power. Proof is the extraordinary attention Russian military élites have increasingly devolved to the reinterpretation of the old Soviet 'active measures' during the last decade, and the impressive sophistication of Moscow's 'sharp power' techniques in the social media landscape. This, along with the progressive disintegration of some of the pillars that govern globalisation and multilateralism due to the global Covid-19 pandemic and, therefore, the increasing danger for the resilience of democratic states and their institutions, should be enough for a clear, ultimate answer to the question above: we should definitely care.

\section{Notes}

1 See, for example: Chekinov and Bogdanov (2012); Kartapolov (2015); Andrianov and Loyko (2015).

2 The term 'hybrid warfare' describes a strategy that builds both on conventional military force and irregular and cyber warfare tactics. For an overview, see Murray and Mansoor (2012) and Lanoszka (2016).

3 Soft power is the ability to affect others to obtain the outcomes one wants through attraction rather than coercion or payment.A country's soft power is built on its culture, values, and policies. The first definition of soft power was coined by Harvard scholar Joseph Nye in 1990. See Nye (1990).

4 In his book, Kurlantzick describes "charm offensive" as the way China uses soft power to appeal to its neighbours and to distant countries alike. The author contends China has wooed the world with a "charm offensive" that has largely escaped the attention of American policy makers, thus allowing Beijing to take advantage of American foreign policy mistakes. See Kurlantzick (2007).

5 The phrase "Little green men" indicates masked soldiers of the Russian Federation wearing unmarked green uniforms who entered Crimea in February-March 2014. While the Russian government initially denied they belonged to the Russian Armed Forces, it eventually confirmed its military presence in Crimea. See Galeotti (2015).

6 On 3 March 2014, two weeks after the Russian invasion of Crimea, EU foreign ministers met in Brussels but could reach no clear agreement on a shared road map to sanction Moscow. Polish Foreign Minister Radoslaw Sikorski told reporters that "the rest of the Europe is sometimes half a phase behind us" (Faiola 2014).

7 See the full report: https://edition.cnn.com/2019/04/18/politics/full-mueller-report$\mathrm{pdf} /$ index.html.

8 Full text of the OSCE press release: www.osce.org/representative-on-freedom-ofmedia/414770. 


\section{References}

Andrianov, V.V., V.V. Loyko (2015) 'Questions regarding the use of the armed forces of the Russian federation in crisis situations in peacetime', Voennaya Mysl' (Mititary Thought) 1: 68 .

Beaumont, R. (1982) Maskirovka: Soviet Camouflage, Concealment and Deception, College Station: Center for Strategic Technology, Texas A\&M University.

Cardenal, J.P., J. Kucharczyk, G. Mesežnikov, G. Pleschová (2017) Sharp Power, Washington DC: National Endowment for Democracy.

Chekinov, S. G., S.A. Bogdanov (2012) "The initial period of war and its influence on the preparation of the country for future wars, Mititary Thought 11: 16.

Chen, A. (2015) 'The agency', The New York Times, 7 June 2015.

Connable, B., S. Young, S. Pezard, A. Radin, R.S. Cohen, K. Migacheva, J. Sladden (2020) Russia's Hostile Measures, Santa Monica: RAND Corporation.

Dougherty, J. (2015) 'How the media became one of Putin's most powerful weapons', The Atlantic, 21 April 2015.

Faiola, A. (2014) 'Europe divided over Russia as NATO meets on Ukraine crisis', The Washington Post, 4 March 2014.

Fried, D., A. Polyakova (2018) 'Democratic defense against disinformation' Atlantic Councit.

Galeotti, M. (2015) "Hybrid war" and "little green men": How it works and how it doesn't', in: A. Pikulicka, R. Sakwa (eds), Ukraine and Russia: People, Politics, Propaganda and Perspectives, Bristol: E-International Relations Publishing.

Galeotti, M. (2018) 'I'm sorry for creating Gerasimov doctrine', Foreign Policy, 5 March 2018.

Gerasimov, V. (2016) "The value of science is in the foresight: New challenges demand rethinking the forms and methods of carrying out combat operations', Military Review, January-February issue.

Giles, K. (2016) 'The next phase of Russian information warfare', NATO Strategic Communications Centre of Excellence.

Giles, K., A. Seaboyer (2018) Russian Reflexive Control, Kingston: Royal Military College of Canada.

Kartapolov, A.V. (2015) 'Lessons of military conflicts, prospects for the development of means and methods of administering them, direct and indirect actions in contemporary international conflicts', Journal of the Academy of Military Science 2(51).

Kurlantzick, J. (2007) Charm Offensive: How China's Soft Power is Transforming the World, New Haven: Yale University Press.

Lanoszka, A. (2016) 'Russian hybrid warfare and extended deterrence in eastern Europe', Intemational Affairs 92(1): 175-95.

Messa, P. (2019) The Age of Sharp Power, Milan: Bocconi University Press.

Murray, W., P.R. Mansoor (eds) (2012) Hybrid Warfare: Fighting Complex Opponents From the Ancient World to the Present, Cambridge: Cambridge University Press.

Nye, J. (1990) 'Soft power', Foreign Policy 80: 153-71.

Nye, J. (2018) 'How sharp power threatens soft power', Foreign Affairs, 24 January 2018.

Paul, C., M. Matthews (2016) The Russian 'Firehose of Falsehood' Propaganda Model, Santa Monica: RAND Corporation.

Petty, R. E., J. T. Cacioppo, A.J. Strathman, J. R. Priester (2005) 'To think or not to think: Exploring two routes to persuasion', in: T. C. Brock, M. C. Green (eds), Persuasion: Psychological Insights and Perspectives, Thousand Oaks: Sage Publications.

Rankin, J. (2020) 'Russian media "spreading Covid-19 disinformation", The Guardian, 18 March 2020. 
Sanovich, S. (2017) 'Computational propaganda in Russia: The origins of digital misinformation', in: S. Wolley, P. Howard (eds), Working Paper 3. Oxford: Project on Computational Propaganda, Oxford: Oxford University Press.

Snegovaya, M. (2015) 'Putin's information warfare in Ukraine', Russia Report.

Thomas, T. (2004) 'Russia's reflexive control: Theory and the military', Joumal of Slavic Mititary Studies, 17(2): 237-56.

Thomas, T. (2016) 'The evolution of Russian military thought: Integrating hybrid, newgeneration, and new-type thinking', Joumal of Slavic Military Studies.

Waltzman, R. (2017) The Weaponization of Information, Santa Monica: RAND Corporation. 